\title{
Association of SIRT1 and HMGA1 expression in non-small cell lung cancer
}

\author{
SHUANG-YAN LIN and FANG PENG \\ Department of Pathology, Zhejiang Hospital, Hangzhou, Zhejiang 310013, P.R. China
}

Received November 13, 2014; Accepted October 9, 2015

DOI: $10.3892 / \mathrm{ol} .2015 .3914$

\begin{abstract}
The roles of Silent mating type information regulation 2 homolog 1 (SIRT1) and High mobility group A1 (HMGA1) in human diseases have been extensively studied separately; however, to the best of our knowledge, the current study is the first to report on their interrelationship in lung cancer. The association of SIRT1 and HMGA1 in non-small cell lung cancer (NSCLC) was investigated by evaluating their expression and prognostic significance in 260 patients with NSCLC using immunohistochemistry. SIRT1 and HMGA1 expression were found to be significantly correlated with each other $(\mathrm{P}<0.001)$, and both were significantly associated with clinicopathological parameters, including histological type and degree of differentiation. In squamous cell carcinoma (SCC), $\mathrm{SIRT}^{+}$specimens were significantly associated with shorter overall survival (OS) time $(\mathrm{P}=0.019)$. However, in patients with adenocarcinoma (AD), no association was identified between SIRT1 and OS. In addition, $\mathrm{HMGA}^{+}$specimens were significantly associated with poor differentiation $(\mathrm{P}=0.028)$, and were more frequent in SCC than AD ( $\mathrm{P}=0.015)$. However, HMGA1 was not associated with OS on univariate Cox regression analysis or Kaplan-Meier analysis (both P>0.05). SIRT1/HMGA1 coexpression was significantly associated with male gender $(\mathrm{P}=0.016)$, and moderately and poorly differentiated histological grade $(\mathrm{P}=0.025)$. The findings indicate that SIRT1 and HMGA1 may have significant effects during tumor progression in NSCLC, particularly in patients with SCC, and are potentially useful as prognostic indicators for patients with NSCLC.
\end{abstract}

\section{Introduction}

Lung cancer is the leading cause of cancer-associated mortality worldwide, and non-small cell lung cancer (NSCLC), which consists predominantly of squamous cell carcinoma (SCC)

Correspondence to: Mrs. Fang Peng, Department of Pathology, Zhejiang Hospital, 12 Lingyin Road, Xihu, Hangzhou, Zhejiang 310013, P.R. China

E-mail: pengfang999@139.com

Key words: non-small cell lung cancer, squamous cell carcinoma, adenocarcinoma, SIRT1, HMGA1 and adenocarcinoma (AD) (1), accounts for $~ 80 \%$ of all lung cancer cases. Thus, understanding of the mechanisms of lung carcinogenesis in NSCLC subtypes is urgently required.

The Silent information regulator 2 (Sir2) family of genes, encoding a group of nicotinamide adenine dinucleotide $\left(\mathrm{NAD}^{+}\right)$-dependent histone deacetylases, is highly conserved from bacteria to humans (2). Mammalian cells possess seven homologs of yeast Sir2, Silent mating type information regulation 2 homologs (sirtuins); these homologs, SIRTs 1-7, have a common catalytic domain with Sir2 (3). SIRT1, which localizes predominantly in the nucleus, is the closest homolog of yeast Sir2 and has been extensively studied. Numerous studies have demonstrated that SIRT1 is overexpressed in various types of cancer, including breast (4), liver (5), prostate (6) and lung cancers $(7,8)$, and that SIRT1 inhibitors are able to suppress tumor growth. SIRT1 is responsible for the deacetylation of various transcription factors that are involved in stress responses and apoptosis, including p53 (9), Ku70 (10), Nuclear factor kB (8), Forkhead box protein $\mathrm{O}$ (11) and Hypermethylated in cancer 1 (HIC1) $(12,13)$.

The High-mobility group A (HMGA) family comprises three proteins (HMGA1a, HMGA1b and HMGA2), which are encoded by two distinct genes; HMGA1a and HMGA1b proteins are generated through alternative splicing of a single gene (14). During embryogenesis, HMGA protein expression is high $(15,16)$, whilst normal adult tissues exhibit low or undetectable HMGA expression. However, high HMGA expression levels have been observed in human malignant neoplasias, including carcinomas of the thyroid (17), colon (18), prostate (19), pancreas (20), cervix (21), ovary (22) and breast (23). Although HMGA proteins alone do not exert transcriptional activity, they are able to alter chromatin structure, and thus regulate the expression of a number of genes, by interacting with the transcription machinery $(24,25)$. Overexpression of HMGA proteins is associated with a highly malignant phenotype and a poor prognostic index, as their overexpression correlates with metastasis and reduced survival time (26). P53 is a well-established tumor suppressor gene (27), the product of which mediates tumor development (28). Recently, HMGA1-p53 interactions have been demonstrated to affect carcinogenesis. HMGA1 binds with $\mathrm{p} 53$, thus interfering with the p53-mediated transcription of BCL2-associated X protein (BAX), P21Waf1, MDM2 and B-Cell CLL/Lymphoma 2 (BCL2); this results in reduced p53-dependent apoptosis (29-31). HMGA1 also inhibits p53 
apoptotic function by relocalizing the nuclear p53 proapoptotic activator Homeodomain-interacting protein kinase 2 (HIPK2) to the cytoplasm (32).

Based on these reports, we hypothesized that SIRT1 may affect the progression of lung cancer in association with HMGA1. To test this, the expression levels of SIRT1 and HMGA1 and the prognostic value of these proteins in NSCLC were investigated. The association between SIRT1 and HMGA1 expression was also evaluated.

\section{Materials and methods}

Patients and tissue samples. Paired tumor and normal lung specimens were obtained from 260 patients with NSCLC who were surgically treated at Zhejiang Hospital (Hangzhou, China) between 2002 and 2010. Informed consent was obtained from the patients, in compliance with the Declaration of Helsinki, and the study was approved by the ethics committee of Zhejiang Hospital (no. 2013-k-2). Clinicopathological data, including gender, age and presence of distant metastasis, were collected from medical records. All cases were reviewed and classified according to the criteria of the World Health Organization (WHO) (33). Pathological staging was based on the Tumor-Node-Metastasis (TNM) staging system of the American Joint Committee on Cancer (34). The patients were grouped according to age, gender, tumor size, TNM stage, histological type, histological grade, tumor invasion (vascular and pleural invasion), presence of lymph node metastasis and smoking history. The mean follow-up period was 37.1 months (range, 0-128 months). All patients were followed up through March 2012. The 260 lung tumors comprised 127 cases of AD and 133 cases of SCC. For the normal lung tissue, 100 of these cases were selected and tissue was taken at a distance of $>3 \mathrm{~cm}$ from the tumor. All specimens were fixed in $10 \%$ neutral formalin.

Immunohistochemical analysis. All tissues were neutral formalin-fixed and paraffin-embedded. Tissues were sectioned into 4- $\mu \mathrm{m}$ slices and then processed using standard deparaffinization and rehydration techniques. Immunohistochemical staining was performed using the enhanced labeled polymer method (35). Briefly, tissue sections were subjected to a boiling antigen retrieval procedure in sodium citrate buffer (pH 6.0; Zhongshan Golden Bridge Biotechnology Co., Ltd., Beijing, China) for 3 min. After blocking endogenous peroxidase activity with peroxidase quenching solution (Zhongshan Golden Bridge Biotechnology Co., Ltd.), the sections were incubated overnight at $4^{\circ} \mathrm{C}$ with a monoclonal rabbit anti-human SIRT1 antibody (clone E104; ab32441; 1:200; Abcam, Cambridge, UK) and a polyclonal rabbit anti-human HMGA1 antibody (ab4078; 1:200; Abcam). Negative control sections were treated in the same manner except they were incubated in phosphate-buffered saline (Zhongshan Golden Bridge Biotechnology Co., Ltd.) without primary antibody. After applying the EnVision System-HRP (Invitrogen) for $20 \mathrm{~min}$, the reaction products were visualized by immersing in a mixture which contained 1 drop of DAB-SuperPicture GenIHC Detection Kit and $1 \mathrm{ml}$ DAB substrate buffer, and the samples were counterstained with hematoxylin (Invitrogen). Immunohistochemical scoring was determined by consensus by two pathologists who were blinded to the clinicopathological information associated with the specimens. SIRT1 and HMGA1 expression levels were semi-quantitatively scored by assessing the intensity of staining ( 0 , no staining; 1 , mild staining; 2 , moderate staining; and 3 , strong staining) and the percentage of positively stained cells $(0,<30 \% ; 1,30-49 \% ; 2,50-69 \%$; and $3, \geq 70 \%$ ). The sum index was obtained by totaling the staining intensity and percentage scores. A final score of $\geq 4$ was considered to indicate positive expression in a specimen; otherwise, the tumor was considered negative, based on the findings of previous reports $(36,37)$.

Statistical analysis. Statistical analysis was performed using SPSS software version 17.0 (SPSS, Inc., Chicago, IL, USA). P-values for differences between groups were determined by $\chi^{2}$ tests. Overall survival (OS) time was calculated from the day of surgery to the date of mortality or the last follow-up. Univariate Cox regression analyses were performed to estimate the effect of clinicopathological factors and expression of each marker on OS. Survival curves were calculated according to the Kaplan-Meier method; comparison was performed using the log-rank test. $\mathrm{P}<0.05$ was considered to indicate statistically significant differences.

\section{Results}

SIRT1 and HMGA1 expression was evaluated immunohistochemically in 260 NSCLC and 100 normal lung specimens (Fig. 1). The median age of the patients was 63 years (range, 35-90 years; Table I). Although immunoreactivity for SIRT1 has been reported in the cytoplasm and the nucleus (38), SIRT1 exhibited only nuclear staining the current study; its score in normal tissues was 0-1. HMGA1 expression was also found to be nuclear, and was weak in normal tissues, with overall scores of 2-3. Among the NSCLC samples, 12 of 133 SCC cases $(9.0 \%)$ were SIRT1 ${ }^{+}$, all exhibiting positive expression in the nucleus. A significantly higher percentage of the AD specimens were $\mathrm{SIRT1}^{+}(18.9 \%$; $\mathrm{P}=0.021$ vs. SCC specimens). $\mathrm{HMGA}^{+}$expression, which was also localized to the cell nuclei, was observed in $62.6 \%$ of NSCLC patients (163 of 260 cases), and was significantly associated with male gender $(\mathrm{P}=0.041)$, histological type $(\mathrm{P}=0.015)$ and degree of differentiation $(\mathrm{P}=0.028)$, and also with positive SIRT1 expression in NSCLC $(\mathrm{P}<0.001)$ (Table I).

To clarify the clinicopathological significance of the combined SIRT1/HMGA1 expression status, the patients were divided into four groups based on SIRT1 and HMGA1 status $\left(\mathrm{SIRT}^{-} / \mathrm{HMGA}^{-}{ }^{-}, \mathrm{SIRT}^{-} / \mathrm{HMGA}^{+}, \mathrm{SIRT}^{+} / \mathrm{HMGA}^{-}\right.$or SIRT $1^{+} / \mathrm{HMGA}^{+}$), and the association with clinicopathological parameters was assessed. As shown in table II, SIRT1 ${ }^{+} / \mathrm{HMGA1}^{-}$ was associated with male gender $(\mathrm{P}=0.016)$ and poorly and moderately differentiated tumors $(\mathrm{P}=0.025)$. Univariate Cox regression analysis of OS time was conducted in the 260 patients with NSCLC for whom complete information for all variables was available. No significant difference in OS time was observed between the four groups $(\mathrm{P}>0.05)$. By contrast, tumor size $(\mathrm{P}=0.049)$, $\mathrm{T} 1$ stage $(\mathrm{P}=0.005)$, T2 stage $(\mathrm{P}=0.006)$, T3/T4 stage $(P=0.002)$, positive lymph node metastasis $(\mathrm{P}<0.001)$ and tumor invasion $(\mathrm{P}=0.047)$ were significantly 
Table I. Association between clinicopathological characteristics and HMGA1 and SIRT1 expression, and their effect on survival in non-small cell lung carcinoma assessed by univariate Cox proportional hazards regression analysis.

\begin{tabular}{|c|c|c|c|c|c|c|c|}
\hline \multirow[b]{2}{*}{ Characteristic } & \multirow[b]{2}{*}{$\mathrm{n}$} & \multicolumn{2}{|c|}{ HMGA1 expression } & \multicolumn{2}{|c|}{ SIRT1 expression } & \multicolumn{2}{|c|}{$\begin{array}{c}\text { Univariate } \\
\text { Cox regression }\end{array}$} \\
\hline & & $\begin{array}{c}\text { Positive, } \\
\text { n (\%) }\end{array}$ & P-value & $\begin{array}{l}\text { Positive, } \\
\text { n (\%) }\end{array}$ & P-value & $\begin{array}{l}\text { Hazard } \\
\text { ratio }\end{array}$ & P-value \\
\hline All & 260 & $163(62.7)$ & & $36(13.8)$ & & & \\
\hline Gender & & & 0.041 & & 0.111 & & \\
\hline Male & 188 & $125(66.5)$ & & $30(16.0)$ & & 1.000 & \\
\hline Female & 72 & $38(52.8)$ & & $6(8.3)$ & & 1.116 & 0.526 \\
\hline Age, years & & & 0.310 & & 0.768 & & \\
\hline$\leq 69$ & 175 & $106(60.6)$ & & $25(14.3)$ & & 1.083 & \\
\hline$>69$ & 85 & $57(67.1)$ & & $11(12.9)$ & & 1.000 & 0.727 \\
\hline Histological type & & & 0.015 & & 0.021 & & \\
\hline Squamous cell carcinoma & 133 & $93(69.9)$ & & $12(9.0)$ & & 1.000 & \\
\hline Adenocarcinoma & 127 & $70(55.1)$ & & $24(18.9)$ & & 0.796 & 0.286 \\
\hline Tumor size, $\mathrm{cm}$ & & & 0.898 & & 0.683 & & \\
\hline$<4$ & 129 & $80(62.0)$ & & $19(14.7)$ & & 1.000 & \\
\hline$\geq 4$ & 131 & $83(63.4)$ & & $17(13.0)$ & & 1.532 & 0.049 \\
\hline T stage & & & 0.300 & & 0.491 & & \\
\hline $\mathrm{T} 1$ & 87 & $53(60.9)$ & & $10(11.5)$ & & & \\
\hline $\mathrm{T} 2$ & 87 & $51(58.6)$ & & $13(14.9)$ & & 2.213 & 0.006 \\
\hline $\mathrm{T} 3 / \mathrm{T} 4$ & 86 & $59(68.6)$ & & $13(15.1)$ & & 3.130 & 0.002 \\
\hline Lymph node metastasis & & & 0.602 & & 0.608 & & \\
\hline Present & 156 & $100(64.1)$ & & $23(14.7)$ & & 1.000 & \\
\hline Absent & 104 & $63(60.6)$ & & $13(12.5)$ & & 0.419 & $<0.001$ \\
\hline Tumor invasion & & & 0.859 & & 0.818 & & \\
\hline Absent & 213 & $133(62.4)$ & & $29(13.6)$ & & 1.000 & \\
\hline Present & 47 & $30(63.8)$ & & 7 (14.9) & & 1.659 & 0.047 \\
\hline Degree of differentiation & & & 0.028 & & 0.300 & & \\
\hline Well & 61 & $31(19.0)$ & & $6(16.7)$ & & 1.000 & \\
\hline Moderate/poor & 199 & $132(81.0)$ & & $30(83.3)$ & & 1.195 & 0.477 \\
\hline Smoking & & & 0.123 & & 0.100 & & \\
\hline Present & 163 & $108(66.3)$ & & 27 (16.6) & & 1.000 & \\
\hline Absent & 97 & $55(56.7)$ & & $9(9.3)$ & & 0.927 & 0.734 \\
\hline HMGA1 expression & & & & & $<0.001$ & & \\
\hline Negative & 97 & & & $4(4.1)$ & & 1.165 & \\
\hline Positive & 163 & & & 32 (19.6) & & 1.000 & 0.477 \\
\hline SIRT1 expression & & & $<0.001$ & & & & \\
\hline Negative & 224 & $131(58.5)$ & & & & 1.000 & \\
\hline Positive & 36 & $32(88.9)$ & & & & 1.024 & 0.939 \\
\hline
\end{tabular}

HMGA1, high mobility group A1; SIRT1, silent mating type information regulation 2 homolog 1.

associated with a shorter OS time on univariate Cox regression analysis (Table I). Kaplan-Meier survival curves for the effect of various factors on OS are shown in Fig. 2. Tumor invasion $(\mathrm{P}=0.043)$, lymph node metastasis $(\mathrm{P}<0.001)$, larger $(\geq 4 \mathrm{~cm})$ tumor size $(\mathrm{P}=0.047)$, higher pathological $\mathrm{T}$ stage $(\mathrm{P}=0.003)$ and $\mathrm{SIRT}^{+} \mathrm{SCC}(\mathrm{P}=0.019)$ predicted shorter OS time in NSCLC patients (Fig. 2).

\section{Discussion}

The present study evaluated SIRT1 and HMGA1 expression immunohistochemically in human NSCLC. Previous studies revealed that SIRT1 can act as a tumor suppressor by repressing a number of oncogenes (39-41). By contrast, SIRT1 expression has been observed to be increased in various human 

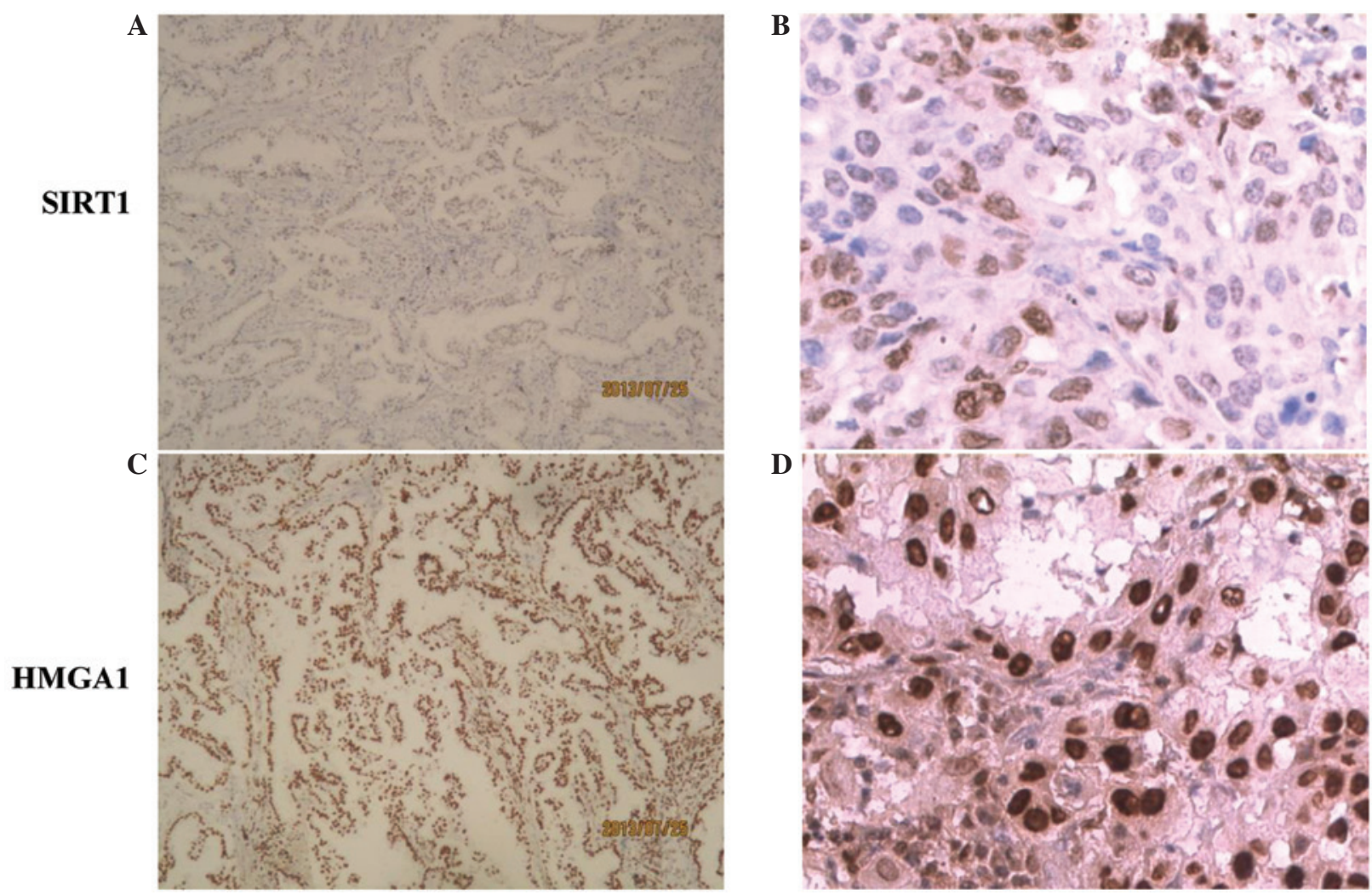

Figure 1. Immunohistochemical staining revealed nuclear expression of (A and B) SIRT1 and (C and D) HMGA1 in non-small cell lung cancer (A and C) Magnification, x100; (B and D) magnification, x400. SIRT1, silent mating type information regulation 2 homolog 1; HMGA1, high mobility group A1.

A

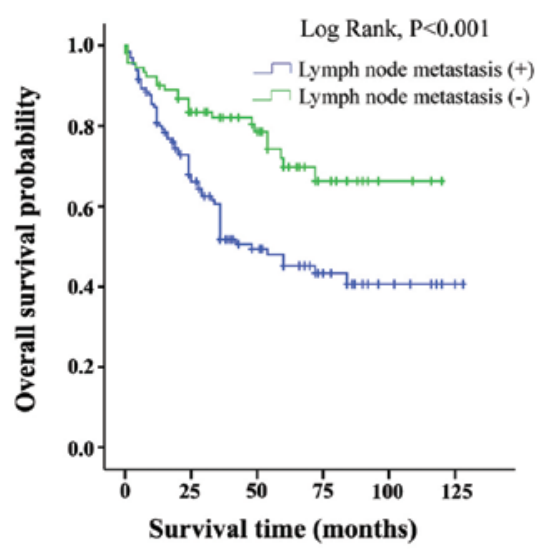

B

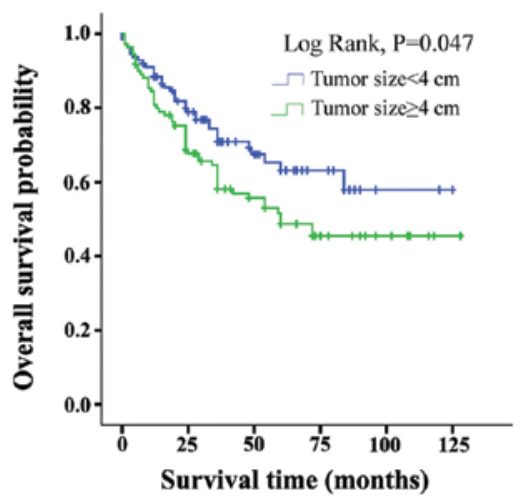

C

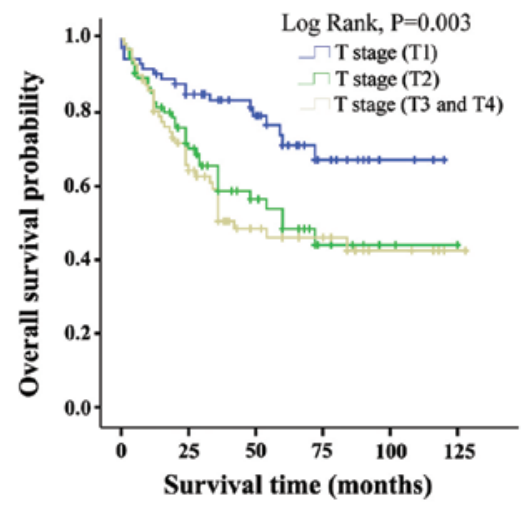

D

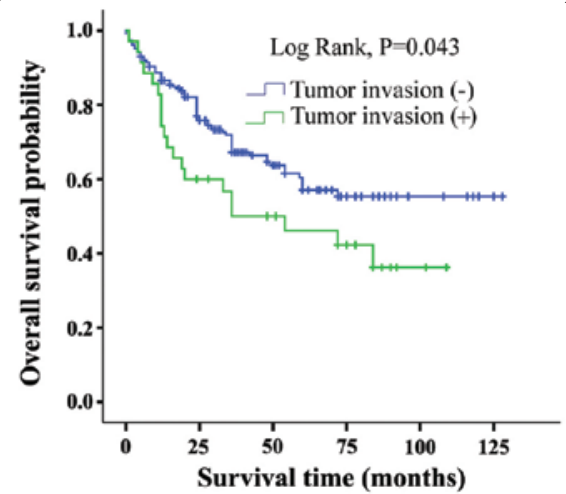

$\mathbf{E}$

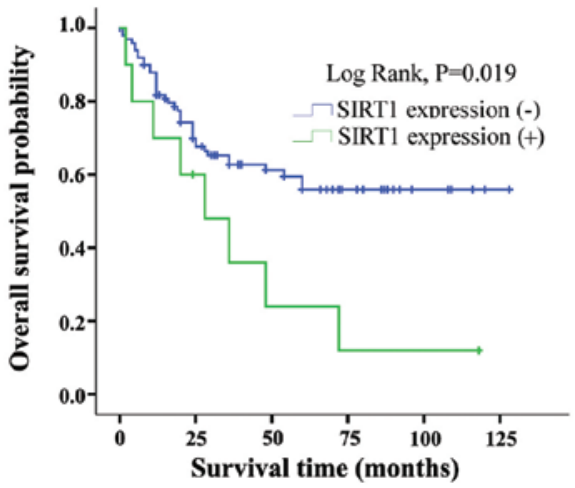

Figure 2. Kaplan-Meier analysis of patients with (A-D) non-small cell lung cancer and (E) squamous cell carcinoma. Overall survival in groups by (A) lymph node metastasis, (B) tumor size, (C) T stage, (D) tumor invasion and (E) SIRT1 expression. P-values were determined by comparing survival distributions using the $\log$ rank test. SIRT1, silent mating type information regulation 2 homolog 1. 
Table II. Association between clinicopathological characteristics and combined expression of HMGA1/SIRT1.

\begin{tabular}{|c|c|c|c|c|c|c|}
\hline \multirow[b]{2}{*}{ Characteristic } & \multirow[b]{2}{*}{$\mathrm{n}$} & \multicolumn{4}{|c|}{ HMGA1/SIRT1 expression, $n$} & \multirow[b]{2}{*}{ P-value } \\
\hline & & $-/-$ & $-/+$ & $+/-$ & $+/+$ & \\
\hline All & 260 & 93 & 4 & 131 & 32 & \\
\hline Gender & & & & & & 0.016 \\
\hline Male & 188 & 61 & 2 & 97 & 28 & \\
\hline Female & 72 & 32 & 2 & 34 & 4 & \\
\hline Age, years & & & & & & 0.427 \\
\hline$>69$ & 85 & 28 & 0 & 46 & 11 & \\
\hline$\leq 69$ & 175 & 65 & 4 & 85 & 21 & \\
\hline Histological type & & & & & & 0.281 \\
\hline Squamous cell carcinoma & 133 & 38 & 2 & 83 & 10 & \\
\hline Adenocarcinoma & 127 & 55 & 2 & 48 & 22 & \\
\hline Degree of differentiation & & & & & & 0.025 \\
\hline Well & 61 & 29 & 1 & 26 & 5 & \\
\hline Moderate and poor & 199 & 64 & 3 & 105 & 27 & \\
\hline Tumor size, $\mathrm{cm}$ & & & & & & 0.124 \\
\hline$<4$ & 129 & 46 & 3 & 64 & 16 & \\
\hline$\geq 4$ & 131 & 47 & 1 & 67 & 16 & \\
\hline T stage & & & & & & 0.255 \\
\hline $\mathrm{T} 1$ & 87 & 33 & 1 & 44 & 9 & \\
\hline $\mathrm{T} 2$ & 87 & 34 & 2 & 40 & 11 & \\
\hline $\mathrm{T} 3 / \mathrm{T} 4$ & 86 & 26 & 1 & 47 & 12 & \\
\hline Lymph node metastasis & & & & & & 0.518 \\
\hline Present & 156 & 53 & 3 & 80 & 20 & \\
\hline Absent & 104 & 40 & 1 & 51 & 12 & \\
\hline Tumor invasion & & & & & & 0.767 \\
\hline Absent & 213 & 76 & 4 & 108 & 25 & \\
\hline Present & 47 & 17 & 0 & 23 & 7 & \\
\hline Smoking & & & & & & 0.064 \\
\hline Present & 163 & 51 & 4 & 85 & 23 & \\
\hline Absent & 97 & 42 & 0 & 46 & 9 & \\
\hline
\end{tabular}

HMGA1, high mobility group A1; SIRT1, silent mating type information regulation 2 homolog 1.

malignancies $(6,42)$, and changes in SIRT1-mediated signaling allows mammalian cells to survive under oxidative stress and DNA damage, which are closely associated with tumorigenesis $(43,44)$, cancer progression and poor prognosis in cancer patients $(3,4,36)$. The present study identified an association of SIRT1 overexpression with shorter OS time and poor prognostic indicators in SCC, which was consistent with the results of previous studies $(4,36,45)$. By contrast, certain reports have found a significant association between SIRT1 overexpression and more favorable prognosis in serous carcinoma of the ovary (46) and colorectal cancer $(47,48)$. In the present study, Kaplan-Meier survival analysis suggested that patients with tumor invasion $(\mathrm{P}=0.043)$, lymph node metastasis $(\mathrm{P}<0.001)$, larger tumor size $(\mathrm{P}=0.047)$ and higher pathological $\mathrm{T}$ stage $(\mathrm{P}=0.001)$ have poorer prognoses (Fig. 2).

In the current study, SIRT $1^{+} \mathrm{SCC}$ was significantly associated with shorter OS time compared with SIRT1- ${ }^{-}$SCC $(\mathrm{P}=0.019)$.
However, no association was identified between SIRT1 expression in $\mathrm{AD}$ and shorter OS. A previous study reported that patients with SCC had significantly higher low-acetylated p53 status compared with patients with $\mathrm{AD}(\mathrm{P}=0.012)$, and that low-acetylated p53 was associated with poorer survival relative to that of patients with acetylated p53 (13). These findings indicate that p53 deacetylation may play a role in lung tumorigenesis, particularly for SCC patients. The different status of p53 acetylation/deacetylation in patients with lung AD and SCC may be caused by the distinct deregulation of SIRT1 epigenetic control (13). In addition, AD is now classified according to its predominant pattern following comprehensive histological subtyping into lepidic, acinar, papillary, solid, mucinous, mixed muciniusand nonmucinous adenocarcinoma, and other subtype $\mathrm{AD}$, based on the WHO classification criteria (33). In the present study, there were 71 cases of lepidic adenocarcinoma, 6 cases of acinar adenocarcinoma, 7 cases of papillary adenocarcinoma, 
4 cases of solid adenocarcinoma, 25 cases of mucinous adenocarcinoma, 14 cases of mixed mucinius and nonmucinous subtype AD, however, no association was identified between SIRT1 expression in AD subtypes and shorter OS. This may be due to the heterogeneity of the subtype of adenocarcinoma, and the pathogenesis of these subtypes is different. Taken together, these results suggest that SIRT1 expression is associated with tumor progression and poor prognosis in NSCLC, particularly for patients with SCC.

HMGA protein overexpression and gene rearrangements are frequent in various types of human cancer (22). HMGA localization appears to be almost exclusively nuclear (30), and was so in the present study. HMGA1 overexpression is associated with a highly malignant phenotype and a poor prognostic index, due to its association with metastasis and reduced survival time (26). Sarhadi et al (49) observed that HMGA1 overexpression was present in all types of lung cancer, and was an independent indicator of poor prognosis, particularly in patients with AD. By contrast, the present study found that neither univariate Cox regression analysis nor Kaplan-Meier survival analysis associated $\mathrm{HMGA}^{+}$expression with poor OS ( $\mathrm{P}>0.05$ for both methods). This discrepancy may be due to a high rate of patients lost to follow-up. However, the present study did identify a clear association between $\mathrm{HMGA}^{+}$expression and poor cellular differentiation $(\mathrm{P}=0.028)$. In addition, SCC patients were more likely to express HMGA1 than AD patients $(\mathrm{P}=0.015)$, and $\mathrm{HMGA}^{+}$expression was significantly associated with male gender $(\mathrm{P}=0.041)$.

To the best of our knowledge, the current study is the first to report on the association between SIRT1 and HMGA1 expression in lung cancer, although their respective roles in tumorigenesis have been widely studied previously $(12-15,26)$. HMGA1 proteins are reported to be important in the process of carcinogenesis, based on the HMGA1-p53 interaction. As p53 functions as a tumor suppressor, P53 mutations commonly lead to the development of cancer. By binding p53, HMGA1 interferes with p53-mediated transcription of BAX, P21Waf1, MDM2 and BCL2, leading to a reduction in p53-dependent apoptosis (29-31). HMGA1 also counteracts p53 transcriptional activity by relocalizing the nuclear p53 proapoptotic activator HIPK2 to the cytoplasm, thereby inhibiting the apoptotic function of p53 (32). SIRT1 is able to promote cell survival or inhibit apoptosis by deacetylating p53 $(50,51)$. Deacetylation of the p53 protein promotes its accumulation during the stress response, and is required for p53-induced apoptosis and arrest of cell growth $(52,53)$. It has been reported that $\mathrm{p} 53$ is responsible for transcriptional repression of SIRT1 in humans and mice, which depends upon p53 response elements in the proximal promoter. The region of the SIRT1 promoter containing the p53-binding sequence also contains a binding site for the transcriptional repressor HIC1 (12). In addition, dysregulation of the HIC1-SIRT1-p53 loop may be involved in lung tumorigenesis and disease outcome (13). Taken together, these results indicate there is a mechanism connecting the expression of SIRT1 and HMGA1. We hypothesized that SIRT1 and HMGA1 may interact with each other by inactivating or activating p53-mediated transcription. Therefore, the current study investigated the possible associations between SIRT1 and HMGA1 expression and the clinicopathological significance of combined expression of these factors in NSCLC. HMGA1 expression was found to be significantly correlated with SIRT1 expression $(\mathrm{P}<0.001)$. SIRT1 ${ }^{+} / \mathrm{HMGA}^{-}$expression was significantly associated with male gender $(\mathrm{P}=0.016)$ and and poorly and moderately differentiated tumors $(\mathrm{P}=0.025$; Table II). Thus, SIRT1 and HMGA1 may cooperate during tumor progression in NSCLC, particularly in patients with SCC.

In conclusion, the present study demonstrated the expression of SIRT1 and HMGA1 in lung cancer and their association with clinicopathological factors and patient survival. NSCLC specimens in this study frequently expressed SIRT1 and HMGA1, and their expression was significantly associated with unfavorable NSCLC characteristics. Furthermore, SIRT1 and HMGA1 expression were found to be significantly correlated in NSCLC patients. SIRT1 and HMGA1 may interact with each other through p53; this mechanism merits further study, as do the SIRT1- and HMGA1-associated pathways that are involved in NSCLC progression.

\section{Acknowledgements}

This work was supported by the Zhejiang Provincial Health Bureau Foundation (grant nos. 2011KYA024 and 2013K YA004).

\section{References}

1. Niklinski J, Niklinska W, Chyczewski L, Becker HD and Pluygers E: Molecular genetic abnormalities in premalignant lung lesions: Biological and clinical implications. Eur J Cancer Prev 10: 213-226, 2001.

2. Imai S, Armstrong CM, Kaeberlein M and Guarente L: Transcriptional silencing and longevity protein Sir2 is an NAD-dependent histone deacetylase. Nature 403: 795-800, 2000.

3. Blander G and Guarente L: The Sir2 family of protein deacetylases. Annu Rev Biochem 73: 417-435, 2004.

4. Lee H, Kim KR, Noh SJ, Park HS, Kwon KS, Park BH, Jung SH, Youn HJ, Lee BK, Chung MJ, et al: Expression of DBC1 and SIRT1 is associated with poor prognosis for breast carcinoma. Hum Pathol 42: 204-213, 2011.

5. Bae HJ, Chang YG, Noh JH, Kim JK, Eun JW, Jung KH, Kim MG, Shen Q, Ahn YM, Kwon SH, et al: DBC1 does not function as a negative regulator of SIRT1 in liver cancer. Oncol Lett 4: 873-877, 2012.

6. Kuzmichev A, Margueron R, Vaquero A, Preissner TS, Scher M, Kirmizis A, Ouyang X, Brockdorff N, Abate-Shen C, Farnham P and Reinberg D: Composition and histone substrates of polycomb repressive group complexes change during cellular differentiation. Proc Natl Acad Sci USA 102: 1859-1864, 2005.

7. Solomon JM, Pasupuleti R, Xu L, McDonagh T, Curtis R, DiStefano PS and Huber LJ: Inhibition of SIRT1 catalytic activity increases p53 acetylation but does not alter cell survival following DNA damage. Mol Cell Biol 26: 28-38, 2006.

8. Yeung F, Hoberg JE, Ramsey CS, Keller MD, Jones DR, Frye RA and Mayo MW: Modulation of NF-kappaB-dependent transcription and cell survival by the SIRT1 deacetylase. EMBO J 23: 2369-2380, 2004.

9. Cheng HL, Mostoslavsky R, Saito S, Manis JP, Gu Y, Patel P, Bronson R, Appella E, Alt FW and Chua KF: Developmental defects and 553 hyperacetylation in Sir2 homolog (SIRT1)-deficient mice. Proc Natl Acad Sci USA 100: 10794-10799, 2003.

10. Cohen HY, Miller C, Bitterman KJ, Wall NR, Hekking B, Kessler B, Howitz KT, Gorospe M, de Cabo R and Sinclair DA: Calorie restriction promotes mammalian cell survival by inducing the SIRT1 deacetylase. Science 305: 390-392, 2004.

11. Brunet A, Sweeney LB, Sturgill JF, Chua KF, Greer PL, Lin Y, Tran H, Ross SE, Mostoslavsky R, Cohen HY, et al: Stress-dependent regulation of FOXO transcription factors by the SIRT1 deacetylase. Science 303: 2011-2015, 2004.

12. Naqvi A, Hoffman TA, DeRicco J, Kumar A, Kim CS, Jung SB, Yamamori T, Kim YR, Mehdi F, Kumar S, et al: A single-nucleotide variation in a p53-binding site affects nutrient-sensitive human SIRT1 expression. Hum Mol Genet 19: 4123-4133, 2010. 
13. Tseng RC, Lee CC, Hsu HS, Tzao C and Wang YC: Distinct HIC1-SIRT1-p53 loop deregulation in lung squamous carcinoma and adenocarcinoma patients. Neoplasia 11: 763-770, 2009.

14. Johnson KR, Lehn DA and Reeves R: Alternative processing of mRNAs encoding mammalian chromosomal high-mobility-group proteins HMG-I and HMG-Y. Mol Cell Biol 9: 2114-2123, 1989.

15. Zhou X, Benson KF, Ashar HR and Chada K: Mutation responsible for the mouse pygmy phenotype in the developmentally regulated factor HMGI-C. Nature 376: 771-774, 1995.

16. Chiappetta G, Avantaggiato V, Visconti R, Fedele M, Battista S, Trapasso F, Merciai BM, Fidanza V, Giancotti V, Santoro M, et al: High level expression of the HMGI (Y) gene during embryonic development. Oncogene 13: 2439-2446, 1996.

17. Chiappetta G, Tallini G, De Biasio MC, Manfioletti G, Martinez-Tello FJ, Pentimalli F, de Nigris F, Mastro A, Botti G, Fedele M, et al: Detection of high mobility group I HMGI(Y) protein in the diagnosis of thyroid tumors: HMGI(Y) expression represents a potential diagnostic indicator of carcinoma. Cancer Res 58: 4193-4198, 1998.

18. Fedele M, Bandiera A, Chiappetta G, Battista S, Viglietto G, Manfioletti G, Casamassimi A, Santoro M, Giancotti V and Fusco A: Human colorectal carcinomas express high levels of high mobility group HMGI(Y) proteins. Cancer Res 56: 1896-1901, 1996

19. Tamimi Y, van der Poel HG, Denyn MM, Umbas R, Karthaus HF Debruyne FM and Schalken JA: Increased expression of high mobility group protein I(Y) in high grade prostatic cancer determined by in situ hybridization. Cancer Res 53 5512-5516, 1993.

20. Abe N, Watanabe T, Izumisato Y, Masaki T, Mori T, Sugiyama M, Chiappetta G, Fusco A, Fujioka Y and Atomi Y: Diagnostic significance of high mobility group $\mathrm{I}(\mathrm{Y})$ protein expression in intraductal papillary mucinous tumors of the pancreas. Pancreas 25: 198-204, 2002.

21. Bandiera A, Bonifacio D, Manfioletti G, Mantovani F, Rustighi A, Zanconati F, Fusco A, Di Bonito L and Giancotti V: Expression of HMGI(Y) proteins in squamous intraepithelial and invasive lesions of the uterine cervix. Cancer Res 58: 426-431, 1998

22. Masciullo V, Baldassarre G, Pentimalli F, Berlingieri MT, Boccia A, Chiappetta G, Palazzo J, Manfioletti G, Giancotti V, Viglietto $\mathrm{G}$, et al: HMGA1 protein over-expression is a frequent feature of epithelial ovarian carcinomas. Carcinogenesis 24 1191-1198, 2003

23. Chiappetta G, Botti G, Monaco M, Pasquinelli R, Pentimalli F Di Bonito M, D'Aiuto G, Fedele M, Iuliano R, Palmieri EA, et al: HMGA1 protein overexpression in human breast carcinomas: Correlation with ErbB2 expression. Clin Cancer Res 10: 7637-7644, 2004.

24. Grosschedl R, Giese K and Pagel J: HMG domain proteins: Architectural elements in the assembly of nucleoprotein structures. Trends Genet 10: 94-100, 1994.

25. Thanos D and Maniatis T: The high mobility group protein HMG $\mathrm{I}(\mathrm{Y})$ is required for NF-kappa B-dependent virus induction of the human IFN-beta gene. Cell 71: 777-789, 1992.

26. Fusco A and Fedele M: Roles of HMGA proteins in cancer. Nat Rev Cancer 7: 899-910, 2007.

27. Sionov RV and Haupt Y: The cellular response to p53: The decision between life and death. Oncogene 18: 6145-6157, 1999.

28. Kruse JP and Gu W: Modes of p53 regulation. Cell 137: 609-622, 2009.

29. Esposito F, Tornincasa M, Federico A, Chiappetta G, Pierantoni GM and Fusco A: High-mobility group A1 protein inhibits p53-mediated intrinsic apoptosis by interacting with Bcl-2 at mitochondria. Cell Death Dis 3: e383, 2012.

30. Pierantoni GM, Rinaldo C, Esposito F, Mottolese M, Soddu S and Fusco A: High Mobility Group A1 (HMGA1) proteins interact with p53 and inhibit its apoptotic activity. Cell Death Differ 13: 1554-1563, 2006

31. Esposito F, Tornincasa M, Chieffi P, De Martino I, Pierantoni GM and Fusco A: High-mobility group A1 proteins regulate p53-mediated transcription of Bcl-2 gene. Cancer Res 70 $5379-5388,2010$

32. Pierantoni GM, Rinaldo C, Mottolese M, Di Benedetto A, Esposito F, Soddu S and Fusco A: High-mobility group A1 inhibits p53 by cytoplasmic relocalization of its proapoptotic activator HIPK2. J Clin Invest 117: 693-702, 2007.

33. Sobin LH: The World Health Organization's Histological Classification of Lung Tumors: A comparison of the first and second editions. Cancer Detect Prev 5: 391-406, 1982.
34. Edge SB and Compton CC: The American Joint Committee on Cancer: The 7th edition of the AJCC cancer staging manual and the future of TNM. Ann Surg Oncol 17: 1471-1474, 2010.

35. Grbesa I, Pajares MJ, Martínez-Terroba E, Agorreta J, Mikecin AM, Larráyoz M, Idoate MA, Gall-Troselj K, Pio R and Montuenga LM: Expression of sirtuin 1 and 2 is associated with poor prognosis in non-small cell lung cancer patients. PLoS One 10: e0124670, 2015.

36. Cha EJ, Noh SJ, Kwon KS, Kim CY, Park BH, Park HS, Lee H, Chung MJ, Kang MJ, Lee DG, et al: Expression of DBC1 and SIRT1 is associated with poor prognosis of gastric carcinoma. Clin Cancer Res 15: 4453-4459, 2009.

37. You TK, Kim KM, Noh SJ, Bae JS, Jang KY, Chung MJ, Moon WS, Kang MJ, Lee DG and Park HS: Expressions of E-cadherin, Cortactin and MMP-9 in pseudoepitheliomatous hyperplasia and squamous cell carcinoma of the head and neck: Their relationships with clinicopathologic factors and prognostic implication. Korean J Pathol 46: 331-340, 2012.

38. Noh SJ, Baek HA, Park HS, Jang KY, Moon WS, Kang MJ, Lee DG, Kim MH, Lee JH and Chung MJ: Expression of SIRT1 and cortactin is associated with progression of non-small cell lung cancer. Pathol Res Pract 209: 365-370, 2013.

39. Luo J, Nikolaev AY, Imai S, Chen D, Su F, Shiloh A, Guarente L and $\mathrm{Gu}$ W: Negative control of p53 by Sir2alpha promotes cell survival under stress. Cell 107: 137-148, 2001

40. Firestein R, Blander G, Michan S, Oberdoerffer P, Ogino S, Campbell J, Bhimavarapu A, Luikenhuis S, de Cabo R, Fuchs C, et al: The SIRT1 deacetylase suppresses intestinal tumorigenesis and colon cancer growth. PLoS One 3: e2020, 2008.

41. Wang RH, Zheng Y, Kim HS, Xu X, Cao L, Luhasen T, Lee MH, Xiao C, Vassilopoulos A, Chen W, et al: Interplay among BRCA1, SIRT1 and Survivin during BRCA1-associated tumorigenesis. Mol Cell 32: 11-20, 2008

42. Stunkel W, Peh BK, Tan YC, Nayagam VM, Wang X, Salto-Tellez M, Ni B, Entzeroth $\mathrm{M}$ and Wood J: Function of the SIRT1 protein deacetylase in cancer. Biotechnol J 2: 1360-1368, 2007

43. Chen WY, Wang DH, Yen RC, Luo J, Gu W and Baylin SB: Tumor suppressor HIC1 directly regulates SIRT1 to modulate p53-dependent DNA-damage responses. Cell 123: 437-448, 2005.

44. Jang KY, Noh SJ, Lehwald N, Tao GZ, Bellovin DI, Park HS, Moon WS, Felsher DW and Sylvester KG: SIRT1 and c-Myc promote liver tumor cell survival and predict poor survival of human hepatocellular carcinomas. PLoS One 7: e45119, 2012

45. Zhang T, Rong N, Chen J, Zou C, Jing H, Zhu X and Zhang W: SIRT1 expression is associated with the chemotherapy response and prognosis of patients with advanced NSCLC. PLoS One 8: e79162, 2013

46. Jang KY, Kim KS, Hwang SH, Kwon KS, Kim KR, Park HS, Park BH, Chung MJ, Kang MJ, Lee DG and Moon WS: Expression and prognostic significance of SIRT1 in ovarian epithelial tumours. Pathology 41: 366-371, 2009.

47. Jang SH, Min KW, Paik SS and Jang KS: Loss of SIRT1 histone deacetylase expression associates with tumour progression in colorectal adenocarcinoma. J Clin Pathol 65: 735-739, 2012.

48. Jung W, Hong KD, Jung WY, Lee E, Shin BK, Kim HK, Kim A and Kim BH: SIRT1 Expression is associated with good prognosis in colorectal cancer. Korean J Pathol 47: 332-339, 2013.

49. Sarhadi VK, Wikman H, Salmenkivi K, Kuosma E, Sioris T, Salo J, Karjalainen A, Knuutila S and Anttila S: Increased expression of high mobility group A proteins in lung cancer. J Pathol 209: 206-212, 2006.

50. Dixit D, Sharma V, Ghosh S, Mehta VS and Sen E: Inhibition of Casein kinase-2 induces p53-dependent cell cycle arrest and sensitizes glioblastoma cells to tumor necrosis factor (TNFa)-induced apoptosis through SIRT1 inhibition. Cell Death Dis 3: e271, 2012.

51. Peck B, Chen CY, Ho KK, Di Fruscia P, Myatt SS, Coombes RC, Fuchter MJ, Hsiao CD and Lam EW: SIRT inhibitors induce cell death and p53 acetylation through targeting both SIRT1 and SIRT2. Mol Cancer Ther 9: 844-855, 2010.

52. Kracikova M, Akiri G, George A, Sachidanandam R and Aaronson SA: A threshold mechanism mediates p53 cell fate decision between growth arrest and apoptosis. Cell Death Differ 20: 576-588, 2013.

53. Zou T, Yang Y, Xia F, Huang A, Gao X, Fang D, Xiong S and Zhang J: Resveratrol Inhibits CD4(+) T Cell Activation by Enhancing the Expression and Activity of Sirt1. PLoS One 8: e75139, 2013 